\title{
PENERAPAN MANAJEMEN KEUANGAN SEDERHANA, PENGUKURAN BIAYA PRODUKSI DAN PENGEMBANGAN PASAR PADA PERUSAHAAN KERUPUK DAN BASRENG “D' RISA" (DRS) KABUPATEN BANDUNG
}

\author{
Dodi Supriyanto \\ dodi.supriyanto@ekuitas.ac.id \\ Cecep Taufiqurrochman \\ ctaofiq@yahoo.com
}

SEKOLAH TINGGI ILMU EKONOMI EKUITAS

\begin{abstract}
ABSTRAK
Sudah menjadi rahasia umum bahwa dalam usaha UMKM itu banyak sekali kelemahankelemahana dalam berbagai sisi. Kelemahan yang paling menonjol dalam kegiatan UMKM itu adalah lemahnya dalam pencatatan keuangan, tidak jelasnya tata kelola karena tidak menggunakan fungsi manajemen dan belum bisa dipisahkan antara harta perusahaan dengan harta pemiliknya. Untuk mengurangi permasalahan dalam UMKM itu antara lain dengan memberikan sosialisasi dan pelatihan tentang penerapan manajemen keuangan, pengukuran biaya produksi dan Pengembangan Pasar. Pengabdian ini menggunakan metode deskriftif melaluikunjungan langsung ke lapangan dan wawancara, hal ini adalah untuk mengetahui gambaran objek yang diteliti secara nyata sesuai dengan kondisi yang ada di lapangan. Dalam pengumpulan data dilakukan dengan wawancara dan on the spot langsung ke objeknya. Disamping itu, dilakukan penelitian kepustakaan.

Berdasarkan hasil pengabdian kepada masyarakat menunjukan bahwa kegiatan usaha ini belum sepenuhnya menggunakan penerapan manajemen keuangan sederhana, pengukuran biaya produksi tidak dilakukan dan tanpa catatan serta pengembangan pasar masih dilakukan dengan cara konservatif. Namun demikian, omset usahanya terus meningkat baik dari produksi baso goreng dan kerupuknya.. Pasar yang sudah di jangkaunya adalah pasar Rangkas Bitung, Tangerang dan Karawang.Penjualan dilakukan cash and carry atau pembayaran dengan waktu tangguh 1 minggu, dimana pembayarannya via bilyet giro atau cek. Dapat disimpulkan bahwa pemasaran yang dilakukan masih tradisional.
\end{abstract}

Kata kunci: Manajemen Keuangan Sederhana, Biaya Produksi dan Pemasaran.

\section{PENDAHULUAN}

Tujuan dari pembangunan nasional adalah meningkatkan kesejahteraan masyarakat seluas-luasnya. Usaha Mikro Kecil dan Menengah memiliki peranan yang sangat penting dalam kehidupan masyarakat kecil, sebagai sarana untuk mengentaskan kemiskinan, sarana meratakan tingkat perekonomian rakyat kelas bawah, serta memberikan devisa bagi negara. Dari peran tersebut tentunya pemberdayaan UMKM menjadi sebuah solusi untuk mendorong pertumbuhan perekonomian nasional dan mengurangi kemiskinan. Pemberdayaan ini juga mampu meningkatkan kegiatan 
perekonomian, khususnya memberantas kemiskinan, menekan pengangguran, serta kesenjangan antar daerah.

Hal ini mengingat bahwa dari data jumlah unit usaha yang ada di Indonesia, 99,9\% merupakan usaha mikro dan kecil. Setiap unit usaha mikro dan kecil ini pun banyak menciptakan lapangan kerja di berbagai daerah. Oleh karenanya, dapat dikatakan pemberdayaan UMKM dapat mengentaskan kemiskinan secara signifikan, salah satu caranya adalah melalui kegiatan pengabdian kepada masyarakat.

Peranan UMKM terutama sejak krisis moneter tahun 1997 dapat dipandang sebagai media penyelamat dalam proses pemulihan ekonomi nasional. Selain sebagai salah satu alternatif penyediaan lapangan kerja baru, UMKM berperan baik dalam mendorong laju pertumbuhan ekonomi dan sebagai program pengentasan kemiskinan maupun penyerapan tenaga kerja. UMKM merupakan suatu bentuk usaha kecil masyarakat yang pendiriannya berdasarkan inisiatif seseorang. Sebagian besar masyarakat beranggapan bahwa UMKM hanya menggunakan pihak-pihak tertentu saja. Padahal sebenarnya UMKM sangat berperan dalam mengurangi tingkat pengangguran yang ada di indonesia. UMKM dapat menyerap banyak tenaga kerja yang masih menganggur, selain itu mereka juga memanfaatkan berbagai sumber daya alam yang potensial di suatu daerah yang belum diolah secara komersial (Budi, 2011).

Dalam upaya mendorong meningkatkan kesejahteraan ini maka perlu adanya dukungan dari pemerintah kepada sektor informal, khususnya kepada dunia usaha mikro, kecil, dan menengah (UMKM). Sektor UMKM ini berjalan dengan baik, maka akan mendorong dan berkontribusi pada distribusi pendapatan. Permasalahan yang terjadi di suatu daerah adalah kurangnya dukungan pemerintah terhadap dunia usaha sektor informal yang banyak menyerap tenaga kerja. Kegiatan UMKM lebih banyak dilakukan oleh ibu rumah tangga dalam upaya untuk membantu penghasilan tambahan rumah tangganya.

Kegiatan sektor informal UMKM banyak dilakukan oleh masyarakat pedesaan maupun masyarakat perkotaan. Bila dilihat dari karakteristiknya jenis usaha ini antara lain tidak menggunakan teknologi, tenaga yang digunakan tidak memiliki keterampilan khusus, usahanya dimiliki oleh keluarga dan menggunakan manajemen sederhana. Hal ini tidak jauh berbeda dengan kegiatan usaha kerupuk dan baso goreng (basreng) di daerah Cimaung Kabupaten Bandung.

Masalah persaingan antar perusahaan mengharuskan perusahaan harus terusmenerus melakukan perbaikan dalam mutu barang dan layanan serta efisiensi dalam menekan biaya produksi sehingga harga penjualan produk tetap dapat bersaing. Pada perusahaan industry kecil, penghasilan yang diperoleh dari hasil penjualan produk yang diolah sendiri dalam hal ini perusahaan manufaktur harus mengolah terlebih dahulu bahan baku melalui proses produksi menjadi barang yang siap dijual, oleh karena itu untuk memperoleh laba yang maksimal perusahaan industri harus benar-benar memperhatikan biaya produksi, sehingga harga pokok produksi dapat ditentukan dengan tepat (Haryono, 2009: 403).

Hasil produksi perusahaan dipengaruhi oleh pengadaan bahan baku, tenaga kerja serta biaya overhead pabrik. Pengadaan bahan baku adalah variabel yang memegang peran penting bagi kelangsungan hidup perusahaan, dengan adanya bahan baku yang tersedia memudahkan perusahaan untuk menjalankan operasinya. Variabel lain adalah tenaga kerja yaitu terdiri dari karyawankaryawan yang melakukan proses produksi. Di samping itu biaya overhead juga merupakan faktor penting karena pada saat produksi berlangsung terdapat biaya tambahan selain biaya diatas.

Usaha Mikro Kecil dan Menengah (UMKM) yang merupakan usaha industri rumah tangga, dibutuhkan perencanaan produksi yang baik jika usaha ini ingin berkembang. Pada kegiatan produksi 
perusahaan, efisiensi biaya sangat diperlukan guna meminimalisasi modal dan peningkatan laba. Untuk menyesuaikan antara biaya pembelian dengan penjualan maka diperlukan perhitungan harga pokok produksinya, sebagai analisa biaya dan pendapatan untuk melihat efisiensi usaha tersebut.

Faktor yang memiliki kepastian yang relatif tinggi yang berpengaruh terhadap penentuan harga jual adalah biaya (Sunarto, 2004:175). Oleh karena untuk memperoleh dan mengolah bahan-bahan menjadi produk jadi dalam kegiatan proses produksi diperlukan dana atau biaya-biaya, maka untuk menutup pengeluaran biaya- biaya tersebut biasanya perusahaan memperhitungkannya dalam penetapan harga jual produk. Kebijakan manajemen dalam penetapan harga jual produk belum dapat memadai jika hanya ditujukan untuk mengganti atau menutup semua biaya yang telah dikeluarkan, tetapi juga harus dapat menjamin adanya laba yang diharapkan, meskipun keadaan yang dihadapi tidak menguntungkan. Walaupun permintaan dan penawaran biasanya merupakan faktor yang menentukan dalam penetapan harga, namun penetapan harga jual produk yang menguntungkan akan tergantung pula pada pertimbangan mengenai biaya.

Penjualan adalah salah satu aktivitas operasi dari koperasi, selain itu penjualan juga merupakan salah satu tujuan utama dari koperasi. Penjualan merupakan bagian yang penting, baik untuk perusahaan industri, perusahaan perdagangan maupun koperasi. "Penjualan (selling) adalah suatu kegiatan yang ditujukan untuk mencari pembeli, mempengaruhi, dan memberi petunjuk agar pembeli dapat menyesuaikan kebutuhannya dengan produksi yang ditawarkan serta mengadakan perjanjian mengenai harga yang menguntungkan bagi kedua pihak." (Moekijat, 2000:488) "Penjualan merupakan suatu transaksi pendapatan yaitu barang atau jasa yang dikirim seorang pelanggan untuk imbalan kas suatu kewajiban untuk membayar." (Amin Wijaya, 2005 : 92) Sedangkan menurut
Philip Kotler yang diterjemahkan oleh Hendra Teguh dalam bukunya yang berjudul "Manajemen Pemasaran" menyatakan bahwa "Penjualan adalah proses sosial yang di dalamnya individu dan kelompok mendapatkan apa yang mereka butuhkan dan inginkan dengan menciptakan, menawarkan, dan secara bebas merupakan produk yang bernilai dengan pihak lain." (Hendra, 2002: 9). Berdasarkan tiga definisi di atas maka dapat disimpulkan bahwa penjualan

Usaha kerupuk ini merupakan kegiatan usaha yang sudah dilakukan secara turuntemurun sejak orang tuanya masih hidup. Dimana usaha ini dilakukan hanya untuk menyambung hidup keluarganya. Konsep usaha yang dijalankannya sangat tradisional dan konservatif, sehingga tidak pernah berpikir untuk dikelola secara modern. Termasuk yang menjadi pekerjanya adalah keluarga dan tetangga terdekat. Namun setelah orang tuanya meninggal, usaha kerupuk ini di wariskan kepada putranya untuk diteruskan dan Alhamdulillah sampai sekarang. Kegiatan usaha kerupuk dilakukan dalam satu tempat dan menyatu dengan tempat tinggal, maka tidaklah heran bila di dalam rumah tempat tinggalnya banyak tumpukan kerupuk yang siap di jual.

\section{Perumusan Masalah}

Berdasarkan uraian di atas, maka dapat dirumuskan permasalah pokok yang akan diteliti dalam penelitian dan pengabdian kepada masyarakat ini adalah sebagai berikut :

1. Belum adanya pencatatan keuangan yang baik sesuai dengan kegiatan transaksinya, dan tidak menggunakan system akuntansi.

2. Belum dilakukannya perhitungan biaya produksi secara benar, sehingga harga jual produknya banya berdasarkan perkiraan.

3. Belum melakukan pengembangan pasar yang menggunakan konsep pemasaran. Pembahasan 
Dalam era digital yang semakin kompetitif sekarang ini, setiap pelaku usaha yang ingin memenangkan persaingan, maka harus lebih kreatif dan inovatif dalam pengembangan produknya sesuai dengan kebutuhan konsumen. Menurut Juran dalam buku "Manajemen Kualitas Penerapan Konsep-Konsep Kualitas dalam Manajemen Bisnis Total" (Vincent Gaspersz, 1997 : 8) untuk menciptakan produk yang berkualitas dan bisa bersaing harus :

1. Menciptakan kesadaran dari kebutuhan dan kesempatan untuk perbaikan/ peningkatan.

2. Memberikan pelatihan tentang bagaimana meningkatkan kualitas.

3. Meninjau kembali kemajuan secara teratur

4. Memberikan penghargaan kepada tim pemenang

5. Memperbaiki system balas jasa (reward system) dalam menjalankan tingkat perbaikan kualitas

6. Mempertahankan momentum melalui perluasan rencana bisnis yang mencakup sasaran untuk peningkatan kualitas.

Terkait dengan isu-isu utama lain yang berhubungan dengan manajemen kualitas, Juran berpendapat bahwa :

1. Siklus pengembangan produk seharusnya dipersingkat melalui perencanaan partisipatif, rekayasa berbarengan (concurrent engineering), dan pelatihan kepada perencanaan dalam metode dan alat-alat manajemen kualitas.

2. Hubungan dengan pemasok harus diperbaiki. Banyaknya pemasok seharusnya dikurangi. Suatu hubungan kerjasama (team work relation) seharusnya di tetapkan berdasarkan rasa saling percaya. Lama kontrak harus diperpanjang sehingga bersifat hubungan jangka panjang.

3. Pelatihan seharusnya berorientasi pada hasil dan bukan orientasi pada alat. Tujuan utama pelatihan seharusnya mengubah perilaku karyawan dan bukan sekadar melatih atau mendidik saja.

Kualitas dianggap sebagai salah satu media untuk melakukan diferensiasi dan penciptaan daya saing. Disamping itu, kualitas memperkuat keinginan konsumen untuk melakukan pembelian secara berulang pada produk yang sama. Untuk dapat mempertahankan dan meningkatkan kualitas atas suatu barang dan jasa perlu adanya manajemen strategis.

Manajemen strategis menurut Lawrence (1996:6) adalah sejumlah keputusan dan tindakan yang mengarah pada penyusunan suatu strategi atau sejumlah strategi yang efektif untuk membantu mencapai sasaran perusahaan. Proses manajemen strategis ialah cara dengan jalan mana para perencanaan strategis menentukan dan mengambil keputusan.

Strategi yang dikembangkan harus mencakup berbagai aspek, termasuk strategi dalam pengelolaan keuangan. Guna mendukung tata kelola keuangan yang baik maka diperlukan manajer keuangan yang memahami kegiatan dalam pengelolaan keuangan. Ada empat aspek penting dalam mengelola keuangan menurut J. Fred Weston (1992 : 3) adalah sebagai berikut :

1. Dalam perencanaan dan perkiraan keuangan, manajer keuangan harus bekerjasama dengan manajer lainnya yang ikut bertanggungjawab atas perencanaan umum perusahaan.

2. Manajer keuangan harus memusatkan perhatian pada berbagai keputusan investasi dan pembiayaanya serta segala hal yang berkaitannya.

3. Manajer keuangan harus bekerjasama dengan para manajer lain di perusahaan itu, agar perusahaan dapat beroperasi secara efisien.

4. Menyangkut penggunaan pasar uang dan pasar modal yang lebih efektif dalam pola investasinya.

Dari ke empat aspek tersebut di atas dapat disimpulkan bahwa manajer keuangan 
pada pokoknya bertugas hanya yang berkaitan dengan investasi dan pembiayaanya. Dalam prakteknya manajer keuangan berkaitan langsung dengan keputusan keuangan yang dapat mempengaruhi nilai perusahaan ke depan.

Analisis terkait dengan kondisi dan potensi wilayah dari segi fisik, ekonomi dan social maupun lingkungan yang relevan dengan kegiatan usaha yang dilakukan adalah sebagai berikut :

\section{Segi Fisik}

Usaha kerupuk dan basreng "DRS" didirikan di atas lahan seluas $250 \mathrm{~m} 2$ yang berlokasi pinggir jalan yang mudah diakses, karena merupakan jalan kabupaten, yaitu Cimaung Pangalengan. Lahan yang dijadikan tempat tinggal dan usaha merupakan milik Bapak Naya Sunarya yang dibelinya dari mertuanya sendiri. Awal usaha, produk yang dihasilkan hanya kerupuk aci yang dibuat secara kecilkecil berbentuk panjang seperti stick dan kerupuk kulit "dorokdok" yang merupakan warisan dari almarhum orang tuanya. Masyarakat sekitarnya menyebut kerupuk itu dengan sebutan "gurilem". Hasil produksi dijual dengan cara tradisional dan lebih banyak dijual diluar daerah Bandung. Diantaranya dijual sampai ke Bitung dan Karawang secara cash and carry. Seiring dengan perkembangan usaha dan kebutuhan konsumen yang makin variatif, maka dilakukan pengembangan produksi basreng. Basreng ini dikemas dan didistribusikan sama dengan kerupuk.

Guna memaksimalkan usahanya, Bapak Naya Sunarya dibantu oleh istrinya untuk mengelola keuangan, sementara untuk kegiatan produksi dan penjualan dibantu oleh 30 orang tenaga kerja lepas yang dibayar secara borongan. Semua kebutuhan produksi mulai dari bahan baku seperti aci, baso, minyak goreng dan lainya dikirim oleh supplier yang sudah berlangganan lama. Dengan demikian kegiatan produksi dan usaha menjadi cepat dan praktis. Untuk pengiriman barang jadi, menggunakan kendaraan sendiri. Sehingga dapat menghemat biaya transportasi.

Sarana dan prasarana yang dimiliki oleh perusahaan kerupuk dan basreng "D Risa" ini adalah sebagai berikut :

1. Satu unit bangunan berupa tempat tinggal dan tempat kegiatan usaha. Tempat kegiatan usaha antara lain untuk penyimpanan persediaan barang, tempat pengolahan adonan dan tempat penyimpanan hasil adonan yang telah diolah.

2. Tempat pengemasan hasil kerupuk yang telah di goreng yang digabungkan dengan tempat penyimpanan jerupuk dan basreng yang siap jual.

3. Satu unit mobil box merk Mitsubishi L.300, sebagai alat transportasi untuk pengiriman barang.

4. Satu unit mesin pres untuk pembungkusan kerupuk dan basreng.

\section{Segi Ekonomi}

Sumber pendapatan utama dalam kegiatan usaha kerupuk dan basreng "DRS" ini adalah hasil penjualan. Selama kegiatan usaha berlangsung belum pernah berhubungan dengan lembaga keuangan baik itu perbankan maupun non bank. Tidak heran bila perputaran usahanya berjalan di tempat. Namun setelah dikenalkan oleh Bapak Adang selaku supplier minyak kelapa kepada lembaga keuangan, barulah terbuka. Kemudian bapak Naya Sunarya mencoba untuk menjadi salah satu nasabah di lembaga keuangan dan akhirnya usahanya berkembang karena ada dorongan pendanaan.

Dana dari lembaga keuangan inilah yang menjadikan Bapak Naya Sunarya untuk mengembangkan usaha basreng dengan merk dagang "DRS". Adanya pengembangan produk basreng ini menjadikan pendapatan usahanya 
menjadi bertambah. Dan akhirnya dapat mendorong pendapatan masyarakat disekitarnya melalui dipekerjakan di usaha Bapak Naya Sunarya.

Tidak hanya itu saja, bahwa sekarang usahanya sudah merambah kepada seblak dengan kemasan gelas. Seblak dengan kemasan gelas ini merupakan hasil pemikiran dan uji coba dari Bapak Naya Sunarya sendiri. Dalam satu gelas kemasan itu berisi 6 bahan seblak dengan bumbunya yang siap saji. Setelah di uji coba dan dirasakan enak, baru dilakukan penjualan dengan jumlah yang terbatas. Dan akhirnya dapat respon positif dari pasar. Dari sinilah mulai dikembangkan produk baru yaitu seblak dengan kemasan gelas.

\section{Segi Sosial}

Untuk masyarakat sekitar wilayah Cimaung sudah mengetahui lokasi usaha kerupuk dan basreng "DRS". Namun untuk masyarakat di luar wilayah Cimaung belum mengetahui dan mengenalnya dengan baik. Di sisi lain, dengan hadirnya usaha kerupuk dan basreng ini telah sedikit memberikan perubahan social, khususnya di wilayah Cimaung. Ibu-ibu disekitar tempat usaha ini yang biasanya diam di rumah tanpa aktivitas usaha, saat ini bias melakukan aktivitas yang menghasilkan uang. Dimana hasilnya ini sedikit banyaknya dapat memberikan tambahan penghasilan bagi keluarganya.

Bagi orang baru akan mengalami kesulitan untuk menemukan tempat usaha kerupuk dan basreng ini, karena tidak menggunakan papan nama yang jelas.

\section{Segi Lingkungan}

Dalam kegiatan usaha memproduksi kerupuk dan basreng ini, Bapak Naya Sunarya kurang memperhatikan lingkungannya, khususnya ditempat usaha. Belum tertatanya ruang untuk produksi, gudang bahan baku dan untuk barang yang siap jual. Yang lebih utama adalah kurang memperhatikan kesterilan tempat untuk proses pembuatan kerupuk dan basreng. Belum lagi pembuangan limbah hasil industri yang tidak memenuhi ketentuan. Dari keseluruhan lingkungan yang ada, belum memenuhi sebagai industry makanan.

5. Kegiatan Pasar dan Pemasaran

Adanya peluang usaha yang sangat baik pada bidang makanan ringan, membuat Bapak Naya Sunaya bersemangat untuk melakukan pengembangan pasar dan produknya. Salah satu produk yang dikembangkan lagi adalah seblak dengan kemasan gelas yang siap saji. Harga satuanya adalah Rp 2.000,- per cup untuk konsumen. Sedangkan harga dari pabriknya adalah Rp 1.600,- per cup. Dengan harga Rp 1.600,- per cup dapat keuntungan Rp 200,- per cup. Setiap bulan dapat menghasilkan omzet sebesar $\mathrm{Rp} 1.600,-$ x 110.000 cup = Rp 176.000.000,-. Biaya produksi per cup Rp 1.400,-, maka Bapak Naya Sunaya dari produksi seblak ini akan menghasilkan laba sebesar Rp 1.600 - Rp $1.400=\mathrm{Rp} 200,-$. Jadi laba yang diperoleh dalam sebulan Rp $200 \mathrm{x}$ 110.000 cup $=\operatorname{Rp} 22.000 .000,-$.

Jika melihat kompetitor yang bergerak dalam jenis usaha yang sama, produk ini masih optimis, karena dipasarkan pada pasar yang berbeda. Artinya Bapak Naya Sunaya sudah mempunyai pasar dan konsumen sendiri. Dimana dalam proses penjualan dilakukan kepada grosir, sehingga penjualan dapat dilakukan dalam jumlah yang besar.

Pasar yang sudah di jangkaunya adalah pasar Rangkas Bitung, Tangerang dan Karawang. Penjualan dilakukan cash and carry atau pembayaran dengan waktu tangguh 1 minggu, dimana pembayarannya via bilyet giro atau cek. Dapat disimpulkan bahwa pemasaran yang dilakukan masih tradisional.

Pengertian akuntansi menurut American Accounting Association (AAA) yang dikutif oleh Sri Nurhayati (2013:1), "The identification, recording, classification, 
interpreting and communication economic events to permit users to make informed decisions". Sesuai dengan pengertian di atas, maka pemilik usaha perlu memahami terlebih dahulu siklus akuntansi, baik yang berpengaruh langsung terhadap keuangan maupun non keuangan. Selain itu baru kepada pemahaman manajemen secara keseluruhan. Langkah selanjutnya adalah memberikan pedoman pencatatan atau kebijakan pencatatan keuangan

\section{METODE PELAKSANAAN}

Dalam pelaksanaan sosialisasi dan pelatihan penerapan laporan keuangan, cara penetapan biaya produksi dan penjualan, dilakukan dengan beberapa tahap ;

1. Melakukan pendataan transaksi yang dilakukan guna kebutuhan dasar dalam pencatatan laporan keuangan melalui pemilahan bukti-bukti, seperti faktur, bon-bon, kwitansi dan juga nota.

2. Memberikan arahan dan pendampingan kepada mitra untuk mencoba dan mencatat sesuai dengan bukti dasar ke dalam buku yang diberikan dengan format standard.

3. Melakukan evaluasi atas hasil pencatatan yang dilakukan oleh mitra sehingga mitra dapat pemahaman yang lebih baik.

4. Dengan adanya pendampingan ini, dapat dijadikan sebagai kegiatan rutin yang harus dikerjakan dan menghasilkan laporan sederhana, paling tidak adanya pemisahan antara penjualan dan pengeluaran. Sehingga mitra mengetahui tentang pertumbuhan dan perkembangan usahanya..

\section{HASIL DAN LUARAN}

Dalam pengabdian ini harus memberikan dampak positif terhadap kegiatan usaha mitra, maka untuk memberikan solusi dan pelatihan tentang pencatatan transaksi hasil penjualan secara sederhana yang menggunakan media buku catatan manual. Hal ini dilakukan untuk memudahkan pembinaan selanjutnya.

Adapun hasil yang dicapai dari hasil pelatihan penerapan manajemen sederhana ini adalah :

1. Sebelum melakukan pelatihan dalam proses pencatatan pada buku manual, terlebih dahulu memberikan penjelasan-penjelasan guna memberikan pemahaman kepada user selama satu hari penuh.

2. Pemilik usaha (mitra) sudah mulai memisahkan kekayaan perusahaan dengan kekayaan pribadi, walaupun belum sepenuhnya. Sehingga mulai menerapkan pencatatan kegiatan transaksi dengan bertahap sesuai dengan tahapan prosesnya.

3. Dalam mengisi buku kegiatan transaksi yang telah di sediakan untuk mencatat hasil kegiatan usaha, lalu melatihnya selama lima hari kerja berturut-turut dengan maksud untuk memberikan pemahaman dan kegunaan pencatatan.

4. Untuk pengembangan pasar, sudah dimulai dengan membuat kemasan untuk produknya sehingga nilai jual mampu ditingkatkan dan akan memudahkan untuk membuka pasar yang baru.

Sampai selesainya pelatihan tersebut, kegiatan pencatatan terus dilakukan walaupun masih sederhana dan manual. Dari kegiatan ini yang paling penting adalah adanya kemauan dan keinginan untuk melakukan perubahan. Sekecil apapun perubahan tersebut semoga memberikan nilai positif bagi pengembangan kegiatan usaha ke depan.

\section{KESIMPULAN}

Berdasarkan hasil penelitian dan pengabdian yang dilakukan pada perusahaan kerupuk dan basreng "DRS" dapat disimpulkan bahwa :

1. Kegiatan usaha ini mempunyai prospek yang baik untuk dikembangkan dengan pola pengelolaan yang baik. Setelah 
adanya pendampingan terhadap mitra selama melakukan pengabdian telah terlihat adanya perubahan untuk melakukan pencatatan.

2. Dalam penetapan biaya produksi, mitra menggunakan pola sederhana, yaitu dengan menghitung belanja bahan baku dengan hasil penjualannya.

3. Mekanisme penjualan dan pengembangan pasar mulai dilakukan dengan memperbaiki kemasan produk yang lebih memberikan nilai jual.

Sehubungan dengan hal tersebut di atas, maka perusahaan ini memerlukan pendampingan secara intensif tahap demi tahap dan berkelanjutan, termasuk peningkatan kualitas sumber daya manusianya.

\section{DAFTAR PUSTAKA}

Budi, Ravik. (2011). Konsep Pemberdayaan Masyarakat Untuk Usaha Kecil dan Mikro. (online). www.ejournal.unud.ac.id. Diakses pada tahun 2018

Fred Weston and Thomas E. Co.peland (1992), Manajemen Keuangan, Jilid I, Edisi 8, Jakarta, Erlangga.

Jusup, Al Haryono. 2009. Dasar-Dasar Akuntansi. Yogyakarta. STIE Yogyakarta.

Roger G. Schroeder (1997), Manajemen Operasi, Jilid I, edisi 3, Jakarta, Erlangga.

Lawrence R. Jauch (1996), Manajemen Strategis dan Kebijakan Perusahaan, edisi 3, Jakarta, Erlangga.

Sunarto. 2004. Akuntansi Manajemen. Yogyakarta. AMUS Yogyakarta.

Vincent Gaspersz (1997), Manajemen Kualitas Penerapan Konsep-Konsep Kualitas Dalam Manajemen Bisnis Total, Jakarta, Gramedia. 